\title{
Profesor Jan Skołyszewski honorowym członkiem Polskiego Towarzystwa Radioterapii Onkologicznej
}

30 marca 2015 roku w Centrum Onkologii — Instytucie im. Marii Skłodowskiej-Curie Oddział w Krakowie Pan Profesor Jan Skołyszewski otrzymał dyplom potwierdzający Jego honorowe członkostwo w Polskim Towarzystwie Radioterapii Onkologicznej. Wręczenia wyróżnienia dokonał Prezes Towarzystwa Profesor Krzysztof Składowski w obecności przedstawicieli Zarządu: dr. med. Tomasza Rutkowskiego oraz prof. CO-I dr hab. med. Beaty Sas-Korczyńskiej.

W uroczystości uczestniczyli dyrektorzy Oddziałów Centrum Onkologii — Instytutu w Krakowie i Gliwicach — prof. dr hab. med. Jerzy Jakubowicz i prof. dr hab. med. Bogusław
Maciejewski oraz licznie zgromadzeni uczniowie, współpracownicy i przyjaciele Profesora. Profesor Marian Reinfuss w wygłoszonej laudacji przypomniał osiągnięcia Profesora Jana Skołyszewskiego jako lekarza, naukowca, wieloletniego Dyrektora Oddziału COI w Krakowie oraz współzałożyciela i pierwszego prezesa PTRO. Prezes PTRO odczytał przysłany przez krajowego konsultanta w dziedzinie radioterapii onkologicznej prof. Rafała Dziadziuszkę list, w którym gratulował wyróżnienia i wskazywał na rolę profesora Jana Skołyszewskiego w rozwoju polskiej radioterapii. Na zakończenie były liczne gratulacje ze strony uczestników uroczystości.

Prof. dr hab. med. Beata Sas-Korczyńska

członek Zarzq̨u PTRO

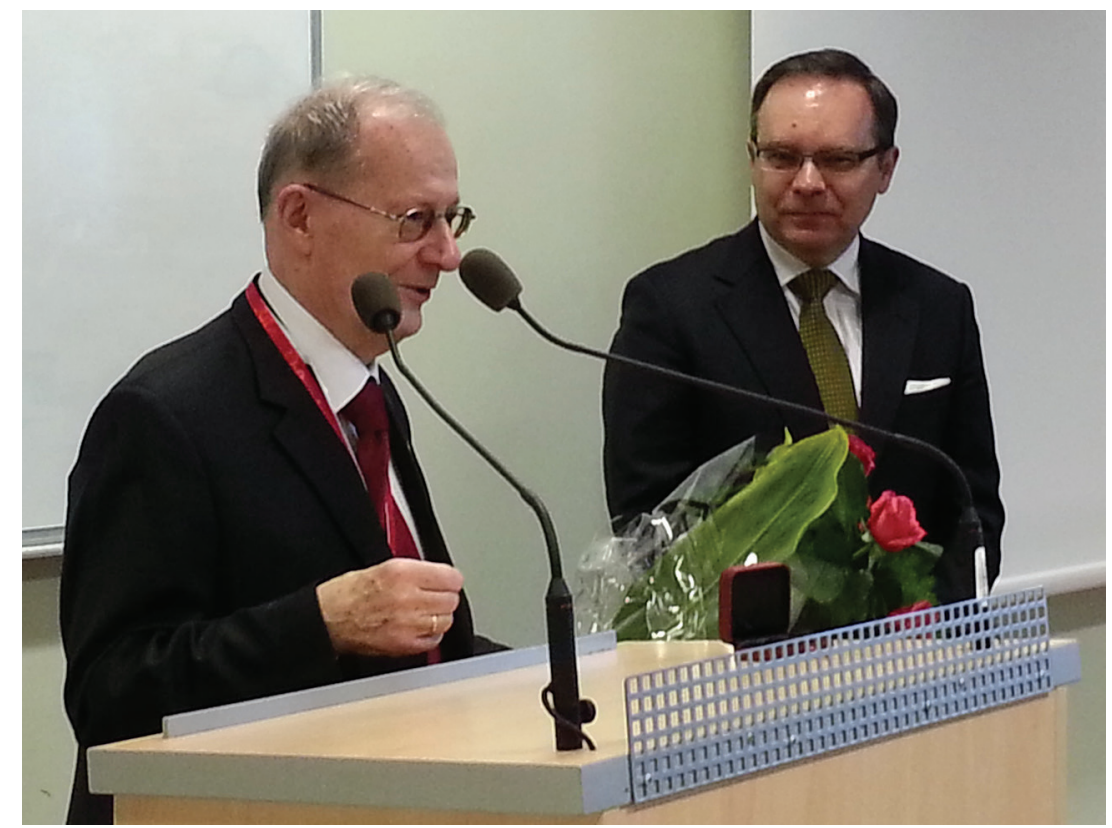

Prof. Jan Skołyszewski, prof. Krzysztof Składowski 


\section{Konferencja Nowotworów "Debaty onkologiczne"}

Konferencja Naukowa czasopisma Nowotwory Journal of Oncology weszła w ostatnich latach na stałe do kalendarza znaczących i cenionych spotkań polskiego środowiska onkologów; jej niezmienny termin — początek kwietnia — nie koliduje z innymi ważnymi wydarzeniami i pozwala na zaplanowanie udziału z odpowiednim wyprzedzeniem.
Pod postacia „debat oksfordzkich" (this house believes...) omawiane są istotne i zarazem kontrowersyjne zagadnienia, a przeciwstawne poglądy przedstawiają osoby o uznanym i niezaprzeczalnym autorytecie. W tym roku obok stałych, zaprawionych w „Debatach" adwersarzy pojawiły sie nowe twarze. Wszyscy potraktowali swój udział z należną powagą,

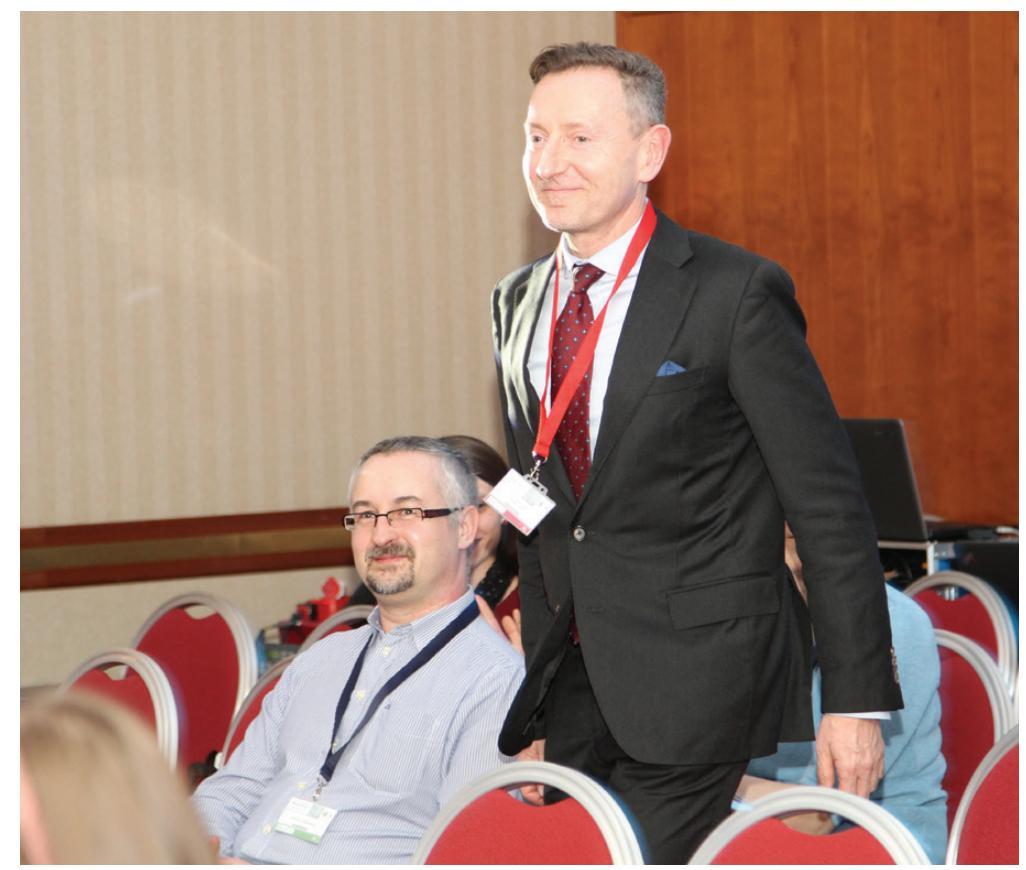

Prof. Jacek Fijuth zmierza na "ring"

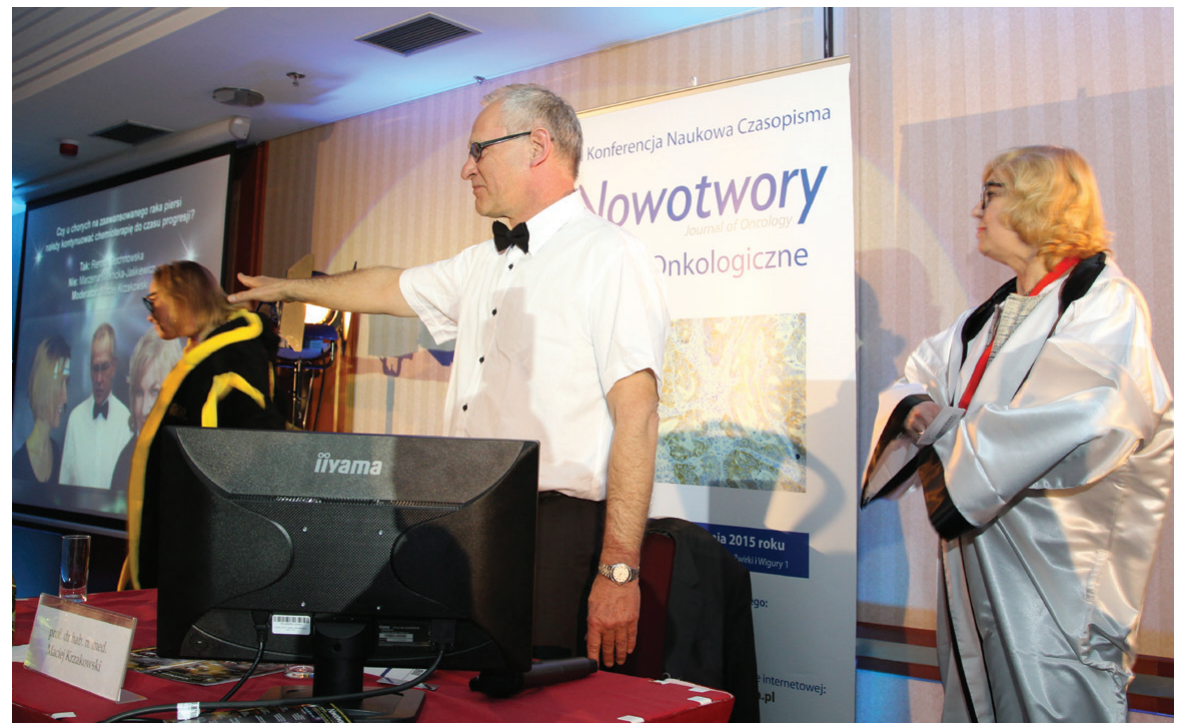

W „narożnikach" szykują się: prof. Renata Duchnowska i prof. Marzena Wełnicka-Jaśkiewicz, za chwilę arbiter — prof. Maciej Krzakowski — da znak do rozpoczęcia starcia 


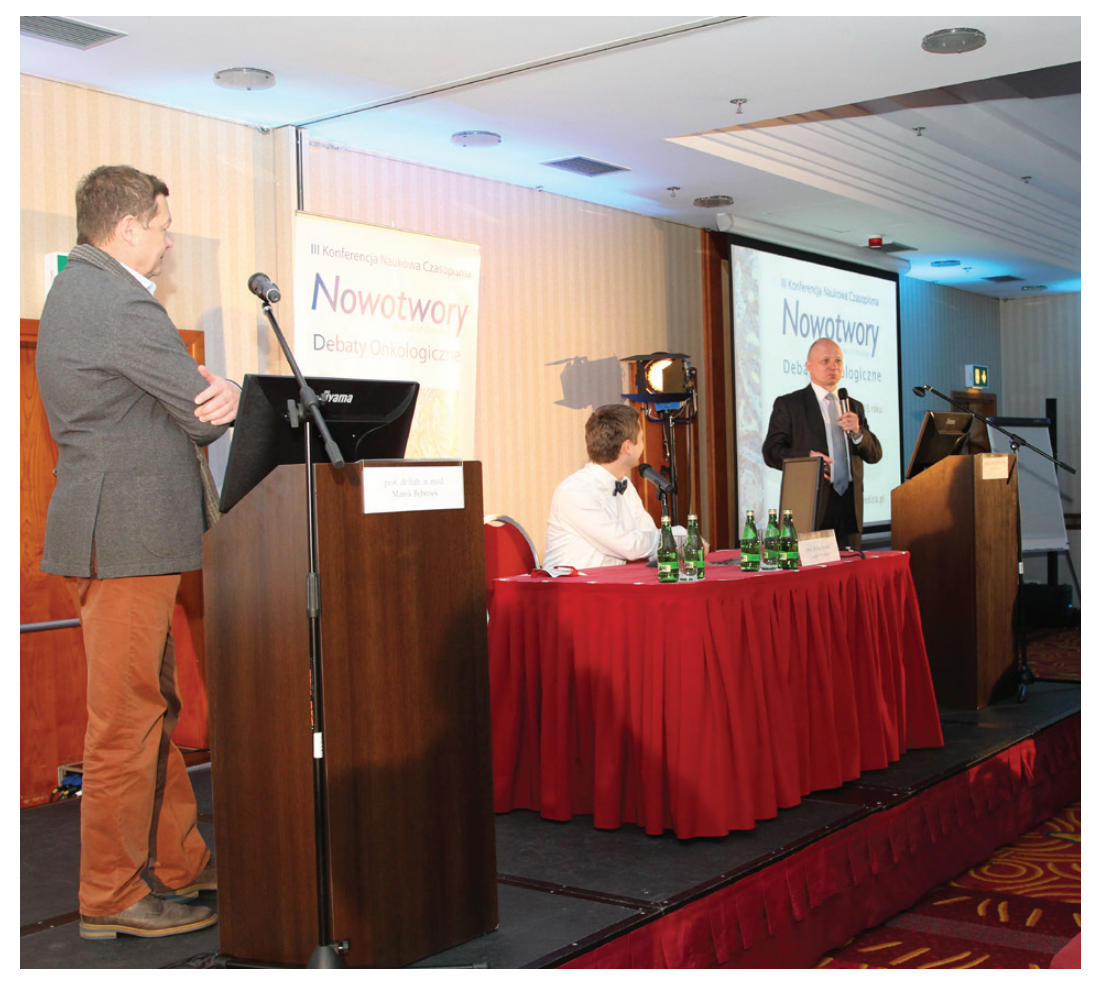

Debata: prof. Marek Bębenek — prof. Piotr Potemski, arbitrem jest prof. Lucjan Wyrwicz

wystąpienia były doskonale przygotowane merytorycznie, a zarazem — co mieści się w konwencji — niepozbawione elementów dramaturgii i szczypty humoru. Dodatkową atrakcją dla słuchaczy jest możliwość wyrażenia swojej opinii przed "starciem" — i po nim, co pozwala ocenić też siłę perswazji i polemiczną werwę dyskutantów.

W „Debatach" obok tematów czysto medycznych pojawiają się zagadnienia o charakterze ogólnym: w tym roku spierano się o potrzebę (lub bezzasadność) funkcjonowania konsultantów krajowych i wojewódzkich oraz o to, czy habilitacja jest w Polsce przeżytkiem.

Rosnąca ranga Konferencji Nowotworów i uczestnictwo czołówki onkologów sprzyjają zwoływaniu podczas jej trwania ważnych zgromadzeń. W tym roku były to: Zarząd Główny Polskiego Towarzystwa Onkologicznego, doroczne Walne Zebranie PTO, Zarząd Główny Polskiego Towarzystwa Chirurgii Onkologicznej, Rada Naukowa Akademii Czerniaka, a w przeddzień - ogólnopolska debata nad przyszłością Cancer Planu.

Przyszłoroczna, IV Konferencja Nowotworów „Debaty onkologiczne", odbędzie się 8 i 9 kwietnia. Prosimy o zaznaczenie tych dni w swoim kalendarzu już dziś.

Redakcja Nowotwory Journal of Oncology 